\title{
Duality or Specialization: The Innovation Performance and the Interaction between Science-Based Innovation and Technology-Based Innovation
}

\author{
Shurong Li \\ School of Business Administration, South China University of Technology, Guangzhou, China \\ Email: shuronlee73@foxmail.com
}

How to cite this paper: Li, S.R. (2017) Duality or Specialization: The Innovation Performance and the Interaction between Science-Based Innovation and TechnologyBased Innovation. Open Journal of Business and Management, 5, 561-576. https://doi.org/10.4236/ojbm.2017.54049

Received: July 20, 2017

Accepted: August 18, 2017

Published: August 21, 2017

Copyright $\odot 2017$ by author and Scientific Research Publishing Inc. This work is licensed under the Creative Commons Attribution International License (CC BY 4.0).

http://creativecommons.org/licenses/by/4.0/ (c) (i) Open Access

\begin{abstract}
This paper examines the impact of the interaction between science-based innovation and technology on innovation performance by using patent data. To do so, we introduce the "Enterprise-Science Correlation Index (ESCI)" and "Enterprise-Technology Correlation Index (ETCI)" based on duality theory. Then we divide Chinese pharmaceutical industry listed companies into duality organization, specialization organization (science-based and technologybased) and other organizations. Three substantive conclusions are as follows. First, both science-based innovation and technology-based innovation have significant positive impact on innovation performance in both duality organizations and specialization organizations. Second, the interaction between science-based innovation and technology-based innovation has a significant positive impact on innovation performance in duality organizations. Third, the interaction between science-based innovation and technology-based innovation has a significant negative impact on innovation performance in specialization organizations.
\end{abstract}

\section{Keywords}

Science-Based Innovation, Technology-Based Innovation, Interaction, Innovation Performance, Pharmaceutical Industry

\section{Introduction}

Tu youyou won the 2015 Nobel Prize in medicine for her discovery of Artemisinin, which indicates that the contribution China's pharmaceutical industry made 
has gradually been internationally recognized. So is the innovation ability of China's pharmaceutical industry really experienced a leap-forward development? Started in 20th century, China's pharmaceutical industry has experienced from scratch to use of traditional technology then to large-scale use of modern technology. Now Chinese pharmaceutical industry has leapt to the world's third largest pharmaceutical market, but it also emerges a lot of problems which highlight that Chinese overall innovation capacity of pharmaceutical companies is limited. Innovation is the lifeblood of the pharmaceutical industry. Chinese pharmaceutical companies focus on imitate foreign drugs based on technologybased innovation and not pay attention to new drugs and medicine based on science-based innovation which lead to the lack of independent intellectual property rights' drugs and the low efficiency of overall innovation performance. Therefore, the study of the interaction between science-based innovation and technology-based innovation has the significant theoretical and practical meaning to adjust the structure of innovation capacity and improve the innovation performance for Chinese pharmaceutical manufacturing enterprises.

The science-based innovation refers to the innovation that is highly relevant to scientific research, and the innovation is totally based on scientific research. The technology-based innovation means that the innovation is highly relevant to existing technology, and the innovation relies on existing technology [1] [2] [3] [4]. Because of the difference in organizational culture and the way of thinking between science-based innovation and technology-based innovation, existing studies implicitly assume that these two ways of organizational learning are incompatible. Though science-based innovation and technology-based innovation can be distinguished clearly, they are interrelated and interacted in actually [5]. For example, if one technology is the result of science-based innovation, but further improvement of the production process may belong to technology-based innovation. Or a company uses new theories which are introduced by sciencebased innovation for further development and application. In terms of the whole innovation system, the science-based innovation has the function of "exploration", while the technology-based innovation is the "exploitation" of the existing knowledge [5]. In the sight of the theory of organizational learning, sciencebased innovation is essentially exploration innovation of scientific research, technology-based innovation is the exploitation innovation of existing technology, there might be duality between these two types of innovation. Based on the duality theory, this paper suggests that companies also need to take advantages of both science-based innovation and technology-based innovation and their interactive effects to achieve optimal innovation performance.

However, it leads to a question that how the companies achieve balance between science-based innovation and technology-based innovation by differentiating or integrating [6]. Focus on the listed companies in China's pharmaceutical industry, we found that those companies can be divided into chemical pharmaceutical companies, bio-pharmaceutical companies and traditional Chi- 
nese medicine pharmaceutical companies. Bio-pharmaceutical companies are characterized by knowledge-intensive, technology-intensive, and highly multidisciplinary integration, so they are most likely to implement both science-based innovation and technology-based innovation activities simultaneously to pursue the impact of their interaction. Chemical pharmaceutical companies are relatively mature in China; they are the main force of China's pharmaceutical industry. But due to chemical \& pharmaceutical industry in China generally manufacture common drug, it mainly focuses on technical innovation instead of the exploration of scientific research, which results in Chinese chemical \& pharmaceutical industry lacking of the medicine with independent intellectual property. As a treasure of our nation, the innovation pattern of traditional Chinese medicine is unique because of its own complexity and the lag of science research. There are different kinds of classification, but nothing more than duality organization and specialization organization. Different types of organizations have differentiated demands for the degree of matching between science-based innovation and technology-based innovation and the specific situation of interaction is also different. Classification discussion helps us to find the differences and rules at the organizational level. As Eisenhardt puts, solving the paradox requires the use of creative methods to capture both extremes at the same time, rather than simply [7].

In this paper, we first classify China's pharmaceutical industry listed companies by clustering method, and then we study the difference and regular pattern of the influence of innovation performance these different types of pharmaceutical companies based on the interaction between science-based innovation and technology-based innovation by constructing a multiple linear regression model. We try to figure out questions blow:

1) What is the impact of science-based innovation and technology-based innovation on innovation performance separately?

2) How does the interaction of these two types of innovation activities affect innovation performance?

3) What are the laws of these relationships in different kind of enterprises?

\section{Theory and Hypothesis}

\subsection{The Impact of Science-Based Innovation and Technology-Based Innovation on Innovation Performance}

On the perspective of the resource concept, the success of technological innovation on organization-level depends on the ability of integrating the knowledge and other complementary resources of the firms. Therefore, there are two main types of innovation pattern of science-based innovation: (1) the innovation is motivated by new scientific research and the result of new scientific discovery [8]. The potential scientific knowledge can be well coded, and the researchers can create new product by learning the journals of science and patents combined with computer simulation programs and human capital and other complemen- 
tary resources, such as the research of chemicals and drugs [2]. (2) The ongoing innovation is promoted by the new scientific achievement, and the new scientific discovery accelerates the innovation process. Most of knowledge is uncoded in many emerging industry, researchers can only partially integrate encoded knowledge because the obtainable prior knowledge is limited. Meanwhile, they need to construct strategic alliance and learn by doing to promote products innovation and process innovation [9]. For example, the innovation pattern of biotechnology and new materials firms. Based on the possibilities and mechanisms of above-mentioned science-based innovation activities, firms can make full use of new scientific research through organizational learning to promote the research and development of unique product and process.

H1. Science-based innovation has a positive impact on firm's innovation performance.

H1a. Science-based innovation has a positive impact on innovation performance in duality organizations.

H1b. Science-based innovation has a positive impact on innovation performance in specialization organizations.

Different from the science-based innovation, the technology-based innovation is described as the evolution of technology itself, that is, new technology is developed by technological breakthroughs, improvements, combinations, adjustments and transform [10]. This kind of innovation mainly transforms the basic technology into general technology or transforms general technology into proprietary technology, such as optimizing the process, improving the technical parameters according to the users' needs. The technology innovation of some traditional industry (such as equipment manufacturing, automobile, highway and bridge engineering, etc.) are mostly incremental innovation and mainly based on optimizing existing technology, which is belonged to technology-based innovation. The accumulation of knowledge learning in the organization stimulate the steady growth of enterprises and guide the $\mathrm{R} \& \mathrm{D}$ researchers to carry out the development and promotion of technical patents, reduce production costs and improve production efficiency through using and integrating a variety of technical means.

H2. Technology-based innovation has a positive impact on firm's innovation performance.

$\mathrm{H} 2 \mathrm{a}$. Technology-based innovation has a positive impact on innovation performance in duality organizations.

H2b. Technology-based innovation has a positive impact on innovation performance in specialization organizations.

\subsection{The Impact of the Interaction between Science-Based Innovation and Technology-Based Innovation on Innovation Performance}

The ability of considering both technologies' utilizes and potential knowledge exploration makes dual-organization to adapt discontinuous change of technol- 
ogy, market and competitive environment in dynamic competitive environment. The science-based innovation and technology-based innovation are interdependent and interactive at the both organizational and systematic level [11] [12]. Successful scientific exploration activities will lay the foundations for further utilization and transformation of technology, and solid technical development activities will foster scientific exploration to provide technical reserves for deeper research [13]. A balance will be achieved when this two kind of innovation activities matched in the scale [14]. He and Wong constructed a measure of relative imbalance and interaction based on strategic fit to research duality [15], and proved the interaction of science-based innovation and technology-based innovation has a positive impact on the sale growth rate empirically. Cao et al. proposed the concept of dual balance dimension and combined dimension and pointed out that a good balance and complementary behaviors can reduce the risk of organization and improve organizational performance. Dual-organizations, which positively undertake the exploration activities of scientific research and existing technology development activities, would keep innovative advantage. Dual-organizations would make stable progress with organizational innovation so that they could achieve better performance [16].

H3. The interaction between science-based innovation and technology-based innovation has a positive impact on innovation performance in duality organizations.

However, Gupta \& Shalley raised questions that does all the organizations have to achieve a dual balance [7]? Does it be sufficient for firms to focus on either science-based innovation or technology-based innovation to keep longterm growth? As the organizations exist in a wide range of social systems, the ability of complement make the firms independent, so it's possible for specialization organization to develop with an imbalanced dual capabilities. Specialization organizations need to meet a few harsh specific conditions to form a longterm interaction at system level theoretically [17], so this paper only explores the interaction within a specialization organization. Specialization organization can be specific divided into scientific organization and technical organization based on the source of innovation. Scientific organization focus on the science-based innovation, such as the firms only do research and development, but the lack of experience in using existing technology will hinder the depth of scientific research and the innovation performance is difficult to maintain a good level in the dynamic environment in the long term. And technical organizations rely on the technology-based innovation, for example, the firms only engage in production. The lack of scientific research will push enterprises into a dilemma, the achievements of innovation only remain in the incremental innovation and imitation innovation. Therefore, the interaction of science-based innovation and technology-based innovation in specialization organizations is weak and even hinders innovation process. Specialization organizations won't keep the advantage of innovation in the long term. 
H4. The interaction between science-based innovation and technology-based innovation has a negative impact on innovation performance in specialization organizations.

We will build a regression model to demonstrate our hypothesis which is described in the following sections.

\section{Data and Methods}

\subsection{Methods}

Patent analysis is an effective way to solve that problem. The cite information system of patents is the linkage to technology and science [9]. In generally, any new inventions and creations are learning from the previous studies, so it's necessary to mention the previous literature or cited literature in the patent. Due to the corporates could research and develop patents with unlimited literatures quotations in which the technique margin is relatively lower [7]. It's reasonable to deduce that science-based innovation and technology-based innovation are complementary rather than alternative based on the sight of patent citing. It conforms to the prerequisite assumptions of the previous section. We can connect the relevant information of past and present, even the future, through the analysis of patent citation, therefore we can find many other information hiding behind the innovation activities.

Citations of patents can be divided into two categories, one is other patents, the other are literatures which includes journal papers, conference papers, dissertations, research publications, technology reports and academic books, are scientific literature. The source of knowledge of patents can be characterized by citing patents and citing scientific literatures [18]. Although the reasons for patent citing of literature and patents are not exactly the same, they are the important access of external knowledge to enter the enterprises, especially to measure the degree of scientific exploration and the degree of technology utilization [19]. Various studies also use the proportion of scientific literature citations to represent the association between patents and basic science [20] [21] [22]. Through studying the citations of patent can clearly identify the source of knowledge and quantify the degree of scientific knowledge exploration and the degree of technology utilization in this paper.

There are also some limitations in using patent data to measure. Previous studies have shown that the preferences of patent citations between different industries are different, but this paper focused on firms in single industry and avoid such interference largely [23]. Despite the lack of intellectual property protection in China, the domestic patent protection of drugs is more perfect. Pharmaceutical industry has shown a strong momentum in patent applications, and the science-based innovation and technology-based innovation often lead to new patents, and system of patent citations can reveal this information to a large extent. 


\subsection{Data Collection and Sample}

The study sample is based on the results of the classification of listed companies in China in the fourth quarter of 2015, which lists 158 pharmaceutical listed companies. The data is found from the China Securities Regulatory Commission. Then we removed the companies with $\mathrm{ST},{ }^{\star} \mathrm{ST}, \mathrm{PT}$ and incomplete documents, got 142 companies left. The application patent data from January 1 st to December 31 th in 2010 of these high-tech companies is downloaded as study sample of this paper to guarantee a 5 -year period of citing for the patent citation has a lag. The data is downloaded from May 1st to May 31th in 2016.

The patent data of this paper is from Derwent Innovations Index (DII). DII is an important product of Thomason Reuters Group and one of the largest patent databases in the world which covers a comprehensive forward citations and backward citation information, has advantages of studying information of patents.

\subsection{Measurement and Variables}

We construct the basic econometric regression model of the impact of sciencebased innovation and technology-based innovation on innovation performance as follow:

$$
A T C_{i}=\alpha_{0}+\alpha_{1} S L_{i}+\alpha_{2} T L_{i}+\alpha_{3} S L_{i} * T L_{i}+\beta Z_{i}+\varepsilon_{i}
$$

In this paper, the average times of citations (ATC) is used as the explanatory variable to measure the innovation performance. The times of citation reflects the technical impact of existing inventions on subsequent inventions [24]. Forward citations are commonly used to measure the innovation performance. Although it has a lot of noise in the performance of agents, this indicator can measure innovation performance to a great extent [25].

The key explanatory variables include science-linkage (SL) and technologylinkage (TL) and cross correlation ( $\mathrm{SL}^{\star} \mathrm{TL}$ ), to measure science-based innovation and technology-based innovation and their interaction separately in this study. The specific defines are as follow: SL refers to the average number of citing science literature of all patents of the company [26] [27] [28]. It can be found from recent application data of patent that the emerging technology-related patents are increasingly inclined to refer to scientific literature [29] [30]. A high level of science linkage indicates that the enterprise's patents are often based on the exploration of scientific knowledge. TL refers to the average number of citing patents of all patents of the company. Similarly, this indicator draws a degree of utilization of existing technology. The independent variables are centrally treated to avoid multiple collinearity effects, and the cross correlation represent the interaction between science-based innovation activities and technologybased innovation activities [31].

$\mathrm{Z}$ represents the set of other variables that may affect the performance of the firm's innovation, includes five control variables: (a) University-Industry Cooperation (UIC). UIC is defined as the proportion of the patents via universi- 
ty-industry cooperation. Zhu et al pointed out that encouraging firms to find external organizations such as university doing research is benefit for firms to access technology [32]. Companies that work closely with universities and institutes are often able to share the results of scientific research first, and the cooperation between enterprises is more about the use of complementary technologies [33]; (b) R \& D intensity. R \& D investment is defined as the proportion of $\mathrm{R} \& \mathrm{D}$ investment expenses for the year. Most scholars believe that increasing $\mathrm{R}$ \& D investment has a significant role in promoting innovation performance; (c) Geographical cluster (GC). Geographical cluster is defined as the area where the enterprise is located by using dummy variables, 0 is for the inland areas and the 1 is for coastal areas. The environment of industry has an important influence on the firm's innovation performance [34]. For example, the Silicon Valley is the model of the electronics industry, South Korea, China Taiwan and Southeast Asia followed by a secondary cluster. These domestic or transnational geographical clusters tend to have greater innovation ability than individual companies [35]; (d) Age of enterprise (Age). Age of enterprise is defined as logarithm of the result of 2015 subtracts the year of enterprise establishment. The current researches do not reach agreement on the issue that the impact of age of enterprise on innovation performance. Because both young and mature enterprises have their own advantages and disadvantages in innovation. The advantage of young enterprise in innovation is that they are easy to accept new ideas and methods, but mature enterprises are expert in innovation due to their relevant experiences and the accumulation of $\mathrm{R} \& \mathrm{D}$ resources. The definition of the regression model is shown as Table 1 .

Table 1. Definition of regression model.

\begin{tabular}{|c|c|c|c|c|}
\hline Index & Name & Definition & Measurement & Literatures \\
\hline ATC & $\begin{array}{l}\text { Average times of } \\
\text { citing }\end{array}$ & $\begin{array}{l}\text { Average times of citing of all } \\
\text { patents }\end{array}$ & $A T C_{i}=\frac{\sum_{j} T C_{i j}}{N_{i}}$ & $\begin{array}{l}\text { Verhoeven et al., } 2016 \\
\text { Van Zeebroeck, } 2011\end{array}$ \\
\hline SL & $\begin{array}{l}\text { Scientific } \\
\text { linkage }\end{array}$ & $\begin{array}{l}\text { Average times of citing } \\
\text { scientific literature of all } \\
\text { patents }\end{array}$ & $S L_{i}=\frac{\sum_{j} N P L_{i j}}{N_{i}}$ & $\begin{array}{l}\text { Zhang, P. \& Lei, J.S., } 2015 \\
\text { Chen, A., et al } 2012\end{array}$ \\
\hline $\mathrm{TL}$ & $\begin{array}{l}\text { Technological } \\
\text { linkage }\end{array}$ & $\begin{array}{l}\text { Average times of citing patents } \\
\text { of all patents }\end{array}$ & $T L_{i}=\frac{\sum_{j} P L_{i j}}{N_{i}}$ & $\begin{array}{c}\text { Wu \& Mathews, } 2012 \\
\text { Schoenmakers et al., } 2010\end{array}$ \\
\hline IE & $\begin{array}{l}\text { Interaction } \\
\text { effect }\end{array}$ & $\begin{array}{l}\text { The product of scientific } \\
\text { linkage and technological } \\
\text { linkage }\end{array}$ & $S L_{i}{ }^{*} T L_{i}$ & $\begin{array}{l}\text { Mladenka et al., } 2015 \\
\text { He \& Wong, } 2004\end{array}$ \\
\hline UIC & $\begin{array}{l}\text { University-indus } \\
\text { try cooperation }\end{array}$ & \multicolumn{2}{|c|}{$\begin{array}{l}\text { The proportion of the patents via } \\
\text { university-industry cooperation }\end{array}$} & $\begin{array}{l}\text { Zhu, G.L., et al, } 2015 \\
\text { Fan, X., et al, } 2011\end{array}$ \\
\hline $\mathrm{RD}$ & R \& D intensity & \multicolumn{2}{|c|}{$\begin{array}{l}\text { The proportion of } \mathrm{R} \& \mathrm{D} \text { investment expenses } \\
\text { for the year }\end{array}$} & $\begin{array}{c}\text { Kim et al., } 2016 \\
\text { Hambrick et al., } 1983\end{array}$ \\
\hline GC & $\begin{array}{l}\text { Geographical } \\
\text { cluster }\end{array}$ & \multicolumn{2}{|c|}{$\begin{array}{l}\text { The area the enterprise located, } 0 \text { is for the } \\
\text { inland and the } 1 \text { is for coastal }\end{array}$} & $\begin{array}{c}\text { Dedrick \& Kraemer, } 2015 \\
\text { Giuliani, } 2005\end{array}$ \\
\hline AGE & $\begin{array}{c}\text { Age of } \\
\text { enterprise }\end{array}$ & \multicolumn{2}{|c|}{$\begin{array}{l}\text { Logarithm of the result of } 2015 \text { subtracts the } \\
\text { year of enterprise establish }\end{array}$} & He \& Wong, 2004 \\
\hline
\end{tabular}




\section{Classification}

\subsection{Classification Method}

Zhang, P. and Lei, J.S. transform the "number of patents with NPL citation/the total number of patents" via mathematic transformation, convert the data into $[-100,100]$ and try to quantify the correlation degree of industry development and scientific research in the quantitative ranking of science-based innovation [9]. This method standardizes the degree of scientific correlation of each industry and uses a uniform standard to describe the differences in the degree of scientific correlation between different industries. This paper put forward the "Enterprise-Science Correlation Index (ESCI)" applied to the organizational level by drawing on the above concepts, to reflect the degree of scientific correlation of different enterprises within the pharmaceutical industry. The greater the value of the positive index, the stronger the enterprise's tendency to science. The greater the absolute value of the negative index, the stronger the enterprise's tendency to technology.

$$
\begin{aligned}
& \text { ETCI }_{j} \\
& =100 S g n\left(\frac{P_{P L, j}}{P_{\text {total }, j}}-\frac{\sum_{i} \frac{P_{P L, i}}{P_{\text {total }, i}}}{i}\right) \sqrt{\left(\frac{P_{P L, j}}{P_{\text {total }, j}}-\frac{\sum_{i} \frac{P_{P L, i}}{P_{\text {total }, i}}}{i}\right) * S g n\left(\frac{P_{P L, j}}{P_{\text {total }, j}}-\frac{\sum_{i} \frac{P_{P L, i}}{P_{\text {total }, i}}}{i}\right)}
\end{aligned}
$$

In Equation (2), $P_{N P L, j}$ is the number of non-patent-literature patents of company $j, P_{\text {total }, j}$ is the total number of patents of company $j$.

We can learn from the ranking of science-based industry of domestic scholars that science-based industry usually refers to the high frequency of science literature cited industry, and the technology-based industry is essentially "non-scientific industry", that is assumed that the innovation motivation of industry (scientific research or existing technology) is incompatible. However the innovation in organizational level is more complex, enterprises can rely on both scientific research and existing technology to innovation, they are not a complete resource competition. Therefore, we made corresponding amendments to the classification, and further put forward the "Enterprise-Technology Correlation Index, ETCI", and use these two indicators to construct a four quadrant maps to classify the enterprises into four types: Dual organization (first quadrant), scientific organization (second quadrant), technical organization (fourth quadrant) and other organization (third quadrant). This classification distinguishes between duality and specialization (including scientific and technical) organizations at the micro level, and categorizes other possible innovation patterns into other organizations at the same time. The enterprises rely on other innovation pattern are noise in research sample because this paper is examining the innovation performance of science-based innovation and technology-based innovation activities, and the modified classification effectively removes such noise from the sample. 
$E^{E T C I}$

$$
=100 \operatorname{Sgn}\left(\frac{P_{P L, j}}{P_{\text {total }, j}}-\frac{\sum_{i} \frac{P_{P L, i}}{P_{\text {total }, i}}}{i}\right) \sqrt{\left(\frac{P_{P L, j}}{P_{\text {total }, j}}-\frac{\sum_{i} \frac{P_{P L, i}}{P_{\text {total }, i}}}{i}\right) * \operatorname{Sgn}\left(\frac{P_{P L, j}}{P_{\text {total }, j}}-\frac{\sum_{i} \frac{P_{P L, i}}{P_{\text {total }, i}}}{i}\right)}
$$

In Equation (3), $P_{P L, j}$ is the number of citing patent-literature patents of company $j, P_{\text {total }, j}$ is the total amount of patents of company $j$.

\subsection{Clustering Results}

We calculated the value of ESCI and ETCI of 142 pharmaceutical listed companies, and established the coordinate based on the result of calculating. ETCI is the $\mathrm{X}$ axis while the ESCI is the $\mathrm{Y}$ axis. The high ESCI value indicates that the innovation activities of the companies are mainly based on scientific exploration. The high ETCI value indicates that the innovation of the companies is mainly based on technology utilization. We got coordinate points based on the ESCI and ETCI values of each company. Then we analyzes the ESCI and ETCI indices of 142 pharmaceutical listed companies, obtains the classification of dual organization and specialization organization, as shown in Figure 1. The companies with a high ESCI value and a low ETCI value or with a high ETCI value and a low ESCI value are belonged to specialization organization (scientific exploration or technology utilization). The companies with both high value in ESCI and ETCI are belonged to duality organization. The rest belongs to other organization. There are 73 companies belong to duality organizations, Sinobioway Biomedicine Co., Ltd., Staidson (Beijing) Biopharmaceuticals Co., Ltd., Shanghai RAAS Co., Ltd., Wolwobiotech Co., Ltd., Zhejiang Medicine Co., Ltd., Zhejiang Hisun Pharmaceutical Co., Ltd., Hybio Pharmaceutical Co., Ltd. are typical dual organizations among them. And 51 companies belong to specialty organization,

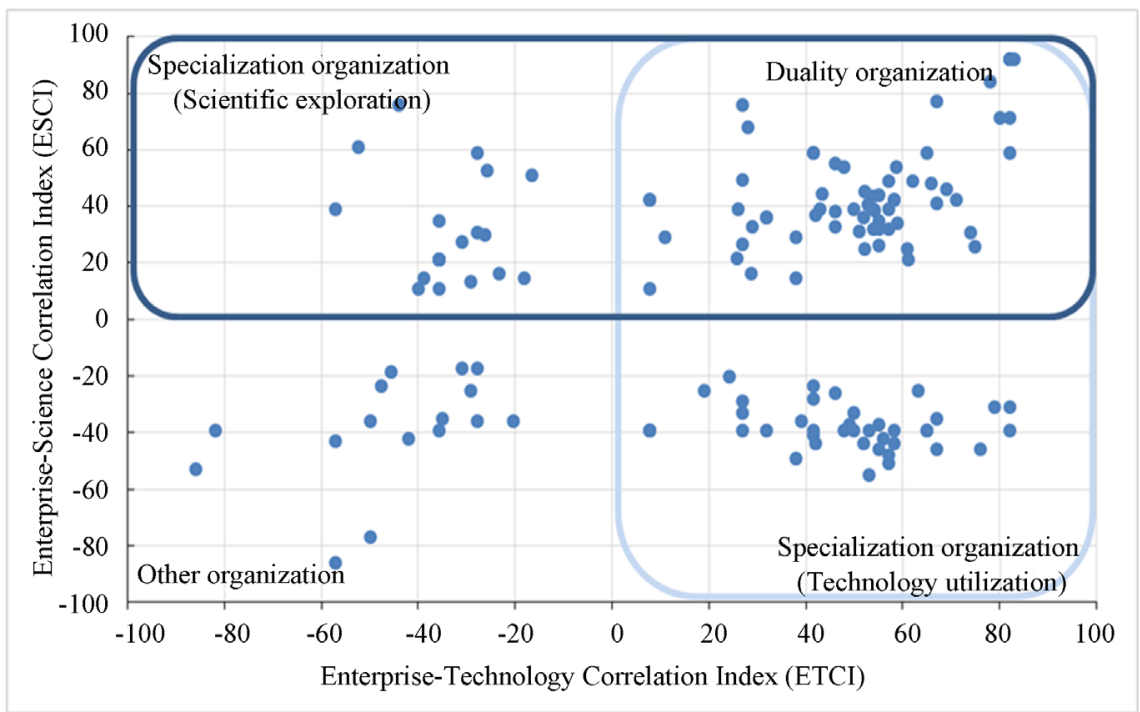

Figure 1. Classification of organizations. 
Shenzhen Salubris Co., Ltd., Jiangsu Kanion Co., Ltd. (scientific organization), Fujian Cosunter Pharmaceutical Co., Ltd., Zhejiang Jinxin Pharmaceutical Co., Ltd. (technical organization) are typical specialty organizations. Other 18 companies are listed as other organizations.

\subsection{Descriptive Statistics}

After extracting the sub-sample 1 (dual organization) and the sub-sample 2 (special organization) from the whole sample, the data collected from two subsamples were analyzed statistically separately, as shown in Table 2 and Table 3. It can be seen from Table 2 that the correlation degree $(r=0.391, p<0.01)$ and the scientific correlation $(\mathrm{r}=0.710, \mathrm{p}<0.01)$ have significant positive correlation with the average times of citing. Meantime, the interaction had a significant positive correlation with the average times of citing $(r=0.643, p<0.01)$. It can be seen from Table 3 that the correlation degree $(r=0.627, p<0.01)$ and the scientific correlation $(r=0.166, p<0.01)$ have a significant positive correlation with the average times of citing. At the same time, the correlation had a significant

Table 2. Descriptive statistics and correlation coefficients of variables (sub-sample 1).

\begin{tabular}{|c|c|c|c|c|c|c|c|c|c|c|}
\hline Variable & Means & $\begin{array}{l}\text { Standard } \\
\text { deviation }\end{array}$ & 1 & 2 & 3 & 4 & 5 & 6 & 7 & 8 \\
\hline GC & 0.616 & 0.490 & 1 & & & & & & & \\
\hline AGE & 9.562 & 6.805 & -0.135 & 1 & & & & & & \\
\hline $\mathrm{R} \& \mathrm{D}$ & 0.038 & 0.025 & $0.585^{\star *}$ & -0.105 & 1 & & & & & \\
\hline UIC & 0.132 & 0.263 & 0.029 & -0.025 & 0.043 & 1 & & & & \\
\hline $\mathrm{TL}$ & 1.814 & 1.621 & $0.386^{\star *}$ & -0.048 & $0.258^{*}$ & 0.001 & 1 & & & \\
\hline SL & 1.208 & 1.374 & 0.374 & -0.313 & $0.366^{* *}$ & 0.036 & 0.076 & 1 & & \\
\hline IE & 2.357 & 3.028 & $0.437^{\star \star}$ & -0.198 & $0.374^{\star *}$ & 0.019 & $0.595^{\star *}$ & $0.743^{\star *}$ & 1 & \\
\hline AVC & 1.483 & 1.067 & $0.601^{\star *}$ & $-0.307^{\star *}$ & $0.540^{\star *}$ & 0.094 & $0.391^{\star *}$ & $0.710^{* *}$ & $0.643^{\star *}$ & 1 \\
\hline
\end{tabular}

Note: ${ }^{*} \mathrm{P}<0.01 ;{ }^{*} \mathrm{P}<0.05$.

Table 3. Descriptive statistics and correlation coefficients of variables (sub-sample 2).

\begin{tabular}{|c|c|c|c|c|c|c|c|c|c|c|}
\hline Variable & Means & $\begin{array}{l}\text { Standard } \\
\text { deviation }\end{array}$ & 1 & 2 & 3 & 4 & 5 & 6 & 7 & 8 \\
\hline GC & 0.569 & 0.500 & 1 & & & & & & & \\
\hline AGE & 10.431 & 6.341 & 0.054 & 1 & & & & & & \\
\hline $\mathrm{R} \& \mathrm{D}$ & 0.045 & 0.024 & $0.572^{\star *}$ & 0.160 & 1 & & & & & \\
\hline UIC & 0.252 & 0.408 & $0.390^{* *}$ & 0.135 & $0.399^{* *}$ & 1 & & & & \\
\hline $\mathrm{TL}$ & 0.876 & 0.796 & $0.353^{*}$ & 0.124 & $0.495^{\star *}$ & $0.443^{\star *}$ & 1 & & & \\
\hline SL & 0.230 & 0.603 & 0.197 & -0.016 & -0.150 & 0.207 & $-0.347^{\star}$ & 1 & & \\
\hline IE & 0.038 & 0.082 & 0.200 & -0.063 & -0.048 & -0.146 & -0.185 & $0.534^{\star *}$ & 1 & \\
\hline AVC & 0.976 & 0.645 & $0.689^{* *}$ & 0.159 & $0.719^{\star *}$ & $0.703^{\star *}$ & $0.627^{\star *}$ & $0.166^{\star *}$ & $-0.034^{\star *}$ & 1 \\
\hline
\end{tabular}

Note: ${ }^{\star * *} \mathrm{P}<0.01 ;{ }^{* \star} \mathrm{P}<0.05$. 
negative correlation with average times of citations $(r=-0.034, p<0.01)$. It is shown that the model and the hypothesis are reasonable and suitable for further examination of the intrinsic mechanism between the variables.

\section{Empirical Results}

Main effect analysis. Main effect analysis is used to analyze the impact of the degree of technical correlation and scientific correlation on innovation performance. This paper first added the control variables into the regression equation and then added the independent variables to analyze; the result is shown as Table 4 . It can be seen from the model 1 based on the regression analysis of subsample 1 (duality organization) that the geographical clustering $(\beta=0.906, \mathrm{P}<$ $0.01)$ and $\mathrm{R} \& \mathrm{D}$ intensity $(\beta=0.597, \mathrm{P}<0.05)$ have significant positive impact on innovation performance, the age of enterprise $(\beta=-0.034, \mathrm{P}<0.05)$ has a significant negative impact on innovation performance. And it can be seen from model 2 that both technical correlation $(\beta=0.147, \mathrm{P}<0.01)$ and scientific correlation $(\beta=0.416, \mathrm{P}<0.01)$ have significant positive impact on innovation performance which prove the $\mathrm{H} 1 \mathrm{a}$ and $\mathrm{H} 2 \mathrm{a}$ is true. In the regression analysis of sub-sample 2 (specialization organization), it can be seen from model 4 that geographical clustering $(\beta=0.400, \mathrm{P}<0.01)$ and $\mathrm{R} \& \mathrm{D}$ intensity $(\beta=0.638, \mathrm{P}<$ $0.01)$ and university-industry cooperation $(\beta=0.685, \mathrm{P}<0.01)$ have significant

Table 4. Regression analysis of interaction between science-based innovation and technology-based innovation.

\begin{tabular}{|c|c|c|c|c|c|c|}
\hline \multirow{2}{*}{ Variable } & \multicolumn{3}{|c|}{ Sub-sample 1 (duality organization) } & \multicolumn{3}{|c|}{$\begin{array}{c}\text { Sub-sample } 2 \\
\text { (specialization organization) }\end{array}$} \\
\hline & Model 1 & Model 2 & Model 3 & Model 4 & Model 5 & Model 6 \\
\hline \multicolumn{7}{|c|}{ Control variable } \\
\hline GC & $0.906^{\star * *}$ & $0.486^{\star *}$ & $0.454^{* *}$ & $0.400^{\star * *}$ & $0.275^{\star * *}$ & $0.302^{* * *}$ \\
\hline AGE & $-0.034^{\star *}$ & -0.013 & -0.010 & 0.003 & 0.002 & 0.001 \\
\hline R \& D & $0.597^{\star *}$ & $0.124^{*}$ & $0.965^{\star}$ & $0.638^{* * *}$ & $0.333^{\star * *}$ & $0.580^{* * *}$ \\
\hline UIC & 0.360 & $0.452^{*}$ & $0.464^{*}$ & $0.685^{\star * *}$ & $0.445^{\star * *}$ & $0.351^{\star * *}$ \\
\hline \multicolumn{7}{|l|}{$\begin{array}{l}\text { Independent } \\
\text { variable }\end{array}$} \\
\hline $\mathrm{TL}$ & & $0.147^{\star * *}$ & $0.276^{\star \star *}$ & & $0.269^{* * *}$ & $0.286^{* * *}$ \\
\hline SL & & $0.416^{* * *}$ & $0.616^{* * *}$ & & $0.250^{\star * *}$ & $0.348^{\star * *}$ \\
\hline IE & & & $0.123^{\star *}$ & & & $-1.100^{*}$ \\
\hline \multicolumn{7}{|l|}{$\begin{array}{l}\text { Result of } \\
\text { regression }\end{array}$} \\
\hline $\mathrm{R} 2$ & 0.472 & 0.714 & 0.732 & 0.784 & 0.848 & 0.859 \\
\hline Adjusted R2 & 0.440 & 0.688 & 0.704 & 0.766 & 0.827 & 0.836 \\
\hline F-statistic & $15 \cdot 17^{\star * *}$ & $27.437^{\star * *}$ & $25.411^{\star * *}$ & $41.831^{* * *}$ & $40.854^{* * *}$ & $37.494^{* * *}$ \\
\hline
\end{tabular}

Note: ${ }^{* *} \mathrm{P}<0.01 ;{ }^{*} \mathrm{P}<0.05 ;{ }^{\star} \mathrm{P}<0.1$. 
positive impact on innovation performance. Both technical correlation $(\beta=$ $0.269, \mathrm{P}<0.01)$ and scientific correlation $(\beta=0.250, \mathrm{P}<0.01)$ have significant positive impact on innovation performance learning from model 5 , that is, H1b and $\mathrm{H} 2 \mathrm{~b}$ are assumed to be established.

Interaction analysis. When the effect of an independent variable is different at each level of another independent variable, it's generally thought that there is an interaction of the independent variables. In this study, we analyze the interaction between technical correlation and scientific correlation to research the impact on innovation performance. For sub-sample 1 (duality organization), the crossterm of technical correlation and scientific correlation is added to the regression equation for regression analysis based on model 2, then the model 3 is obtained. The interaction of these two has a significant positive impact on innovation performance and the $\mathrm{H} 3$ is proved. For sub-sample 2 (specialization organization), the cross-term of technical correlation and scientific correlation is added to the regression equation for regression analysis based on model 5, then the model 6 is obtained. The interaction of these two has a significant negative impact on innovation performance and the $\mathrm{H} 4$ is proved.

\section{Conclusions}

On the perspective of dualism theory, this paper proposed that there is interaction between science-based innovation and technology-based innovation on the basis of the information of patent citations which overcome the shortage of single perspective of only science-based innovation or technology-based innovation. We built a reasonable classification method and divided China's pharmaceutical companies into duality organization, specialization organization and other organizations to study the different laws of different kinds of organizations. Three main conclusions and contributions are listed as follows.

First, both science-based innovation and technology-based innovation have significant positive impact on innovation performance in both duality organization and specialization organization. The utilization of existing technology and scientific research are the fundamental driving force of short-term survival and long-term development of China's pharmaceutical companies from the point of view of innovation source. Research in the fields like life science and biomedicine and other fields has found a blowout situation in recent years. If the pharmaceutical manufacturers can seize the opportunity to discover and transform these studies, they can greatly improve their innovation performance.

Second, the interaction between science-based innovation and technologybased innovation has a significant positive impact on the innovation performance in duality organization. Biomedical enterprises are typical duality organizations, which are characteristic by knowledge-intensive, high-tech, highly multi-disciplinary integrated and penetration. These properties determine that such companies are most likely to simultaneously implement science-based innovation and technology-based innovation activities. On the one hand, the scientific 
exploration activities of frontier biopharmaceuticals lay the foundations for the further use and transformation of existing technologies. On the other hand, solid technical development activities will foster scientific exploration capabilities and provide technical reserves for more in-depth scientific research. Good balance and complementary behavior can reduce the risk of organization and improve organizational innovation performance.

Third, the interaction between science-based innovation and technologybased innovation has a significant negative impact on innovation performance in specialization organization. Chemical pharmaceutical is relatively mature in China; companies of chemical pharmaceutical industry are the main force in China's pharmaceutical industry. However, due to China's chemical pharmaceutical focus on ordinary drugs, enterprises are committed to improving technical processed and ignoring the exploration of scientific research which makes technology-based innovation and science-based innovation relatively imbalance and the transformation of cutting edge scientific research results inefficient. The possibility of upgrading the existing technology is limited, it's difficult to form a special drug, new drugs and the market which is one of the main reasons that China's lack of pharmaceutical independent intellectual property rights.

This study also has limitations. This paper focuses on the interaction between science-based innovation and technology-based innovation, buy only involves the system level of duality balance in terms of university-industry cooperation patents. However, some scholars point out that duality balance also exists in a wide range of social systems and the interdependent relationship can be formed between the subjects of complementary abilities which point out the direction for research group to do further study of patterns, path and mechanism and other issues of both science-based innovation and technology-based innovation based on the duality theory.

\section{References}

[1] Pavitt, K. (1984) Sectoral Patterns of Technical Change: Towards a Taxonomy and a Theory. Research Policy, 13, 343-373. https://doi.org/10.1016/0048-7333(84)90018-0

[2] Cardinal, L.B., Alessandri, T.M. and Turner, S.F. (2001) Knowledge Codifiability, Resources, and Science-Based Innovation. Journal of Knowledge Management, 5, 195-204. https://doi.org/10.1108/13673270110393266

[3] Coriat, B. (2003) Does Biotech Reflect a New Science-Based Innovation Regime? Industry \& Innovation, 10, 231-253. https://doi.org/10.1080/1366271032000141634

[4] Chen, J., Zhao, X.T. and Liang, L. (2013) Science-Based Innovation. Science of Science and Management of S. \& T., 34, 3-7.

[5] Lin, B. and Lei, J.S. (2014) Science-Based Innovation and Technology-Based Innovation: Sectoral Patterns of Science-Technology Relationship. Studies in Science of Science, 32, 1289-1296.

[6] Gupta, A.K. and Shalley, C.E. (2006) The Interplay between Exploration and Exploitation. Academy of Management Journal, 49, 693-706. https://doi.org/10.5465/AMJ.2006.22083026 
[7] Eisenhardt, K.M. (2000) Paradox, Spirals, Ambivalence: The New Language of Change and Pluralism. Academy of Management Review, 25, 703-705. https://doi.org/10.5465/AMR.2000.3707694

[8] Zhang, P. and Lei, J.S. (2015) Science-Based Innovation and Industries: Related Concepts and Typical Industries Identification. Studies in Science of Science, 33, 1313-1323.

[9] Pisano, G.P. (2006) Knowledge, Integration, and the Locus of Learning: An Empirical Analysis of Process Development. Strategic Management Journal, 15, 85-100. https://doi.org/10.1002/smj.4250150907

[10] Arthur, W.B. (2007) The Structure of Invention. Research Policy, 21, 10436-10442. https://doi.org/10.1016/j.respol.2006.11.005

[11] Beckman, C.M. (2006) The Influence of Founding Company Affiliations on Firm Behavior. Academy of Management Journal, 49, e101120-e101120. https://doi.org/10.5465/AMJ.2006.22083030

[12] Raisch, S., Birkinshaw, J., Probst, G. and Tushman, M.L. (1994) Organizational Ambidexterity: Balancing Exploitation and Exploration for Sustained Performance. Organization Science, 20, 685-695. https://doi.org/10.1287/orsc.1090.0428

[13] Bierly, P.E. and Daly, P.S. (2007) Alternative Knowledge Strategies, Competitive Environment, and Organizational Performance in Small Manufacturing Firms. Entrepreneurship Theory \& Practice, 31, 493-516. https://doi.org/10.1111/j.1540-6520.2007.00185.x

[14] Lavie, D., Stettner, U. and Tushman, M.L. (2010) Exploration and Exploitation within and across Organizations. Academy of Management Annals, 4, 109-155. https://doi.org/10.1080/19416521003691287

[15] He, Z.L. and Wong, P.K. (2004) Exploration vs. Exploitation: An Empirical Test of the Ambidexterity Hypothesis. Organization Science, 15, 481-494. https://doi.org/10.1287/orsc.1040.0078

[16] Stettner, U. and Lavie, D. (2014) Ambidexterity under Scrutiny: Exploration and Exploitation via Internal Organization, Alliances, and Acquisitions. Strategic Management Journal, 35, 1903-1929. https://doi.org/10.1002/smj.2195

[17] Benner, M.J. and Tushman, M.L. (2003) Exploitation, Exploration, and Process Management: The Productivity Dilemma Revisited. Academy of Management Review, 28, 238-256.

[18] Chen, A., Liu, X.L. and Gao, G.Y. (2012) The Formation Characteristics of Highly Cited Patents in Emerging Industry Based on Fuel Cell Industry. Science Research Management, 33, 9-15.

[19] Schmoch, U. (1993) Tracing the Knowledge Transfer from Science to Technology as Reflected in Patent Indicators. Scientometrics, 26, 193-211. https://doi.org/10.1007/BF02016800

[20] Trajtenberg, M., Henderson, R. and Jaffe, A. (1997) University versus Corporate Patents: A Window on the Basicness of Invention. Economics of Innovation \& NeW Technology, 5, 19-50. https://doi.org/10.1080/10438599700000006

[21] Narin, F., Hamilton, K.S. and Olivastro, D. (1997) The Increasing Linkage between U.S. Technology and Public Science. Research Policy, 26, 317-330. https://doi.org/10.1016/S0048-7333(97)00013-9

[22] Meyer, M. (2000) Does Science Push Technology? Patents Citing Scientific Literature. Research Policy, 29, 409-434. https://doi.org/10.1016/S0048-7333(99)00040-2

[23] Katila, R. and Ahuja, G. (2002) Something Old, Something New: A Longitudinal 
Study of Search Behavior and New Product Introduction. Academy of Management Journal, 45, 1183-1194. https://doi.org/10.2307/3069433

[24] Verhoeven, D., Bakker, J. and Veugelers, R. (2016) Measuring Technological Novelty with Patent-Based Indicators. Research Policy, 45, 707-723. https://doi.org/10.1016/j.respol.2015.11.010

[25] Van Zeebroeck, N. (2011) The Puzzle of Patent Value Indicators. Economics of Innovation and New Technology, 20, 33-62. https://doi.org/10.1080/10438590903038256

[26] Harhoff, D., Scherer, F.M. and Vopel, K. (2003) Citations, Family Size, Opposition and the Value of Patent Rights. Research Policy, 32, 1343-1363. https://doi.org/10.1016/S0048-7333(02)00124-5

[27] Narin, F. and Olivastro, D. (1998) Linkage between Patents and Papers: An Interim EPO/US Comparison. Scientometrics, 41, 51-59. https://doi.org/10.1007/BF02457966

[28] Tijssen, R.J.W. (2001) Global and Domestic Utilization of Industrial Relevant Science: Patent Citation Analysis of Science-Technology Interactions and Knowledge Flows. Research Policy, 30, 35-54. https://doi.org/10.1016/S0048-7333(99)00080-3

[29] Motohashi, K. and Tomozawa, T. (2014) Differences in Science Based Innovation by Technology Life Cycles: The Case of Solar Cell Technology. Discussion Papers, 72,5 .

[30] Wu, C.Y. and Mathews, J.A. (2012) Knowledge Flows in the Solar Photovoltaic Industry: Insights from Patenting by Taiwan, Korea and China. Research Policy, 41, 524-540. https://doi.org/10.1016/j.respol.2011.10.007

[31] Popadić, M., Černe, M. and Milohnić, I. (2015) Organizational Ambidexterity, Exploration, Exploitation and Firms Innovation Performance. Organizacija, 48, 112 119. https://doi.org/10.1515/orga-2015-0006

[32] Zhu, G.L., Zhang, Y. and Chen, K.H. (2015) The Evolution of the International Research on University-Industry Collaboration. Studies in Science of Science, 33, 1669-1686.

[33] Fan, X., He, Y. and Zhu, G.L. (2011) Research on the Complementary between University-Industry Cooperation and Enterprise Internal R \& D. Studies in Science of Science, 29, 764-770.

[34] Dedrick, J. and Kraemer, K.L. (2015) Who Captures Value from Science-Based Innovation? The Distribution of Benefits from GMR in the Hard Disk Drive Industry. Research Policy, 44, 1615-1628. https://doi.org/10.1016/j.respol.2015.06.011

[35] Giuliani, E. (2005) Cluster Absorptive Capacitywhy Do Some Clusters Forge Ahead and Others Lag Behind? European Urban \& Regional Studies, 12, 269-288. https://doi.org/10.1177/0969776405056593 